\title{
ARTIKEL PENELITIAN \\ KEPADATAN VEKTOR DEMAM BERDARAH DENGUE DI PERUMNAS SITEBA PADANG TAHUN 2008
}

\author{
Nuzulia Irawati \\ Bagian Parasitologi Fakultas Kedokteran Universitas Andalas \\ E-mail: nuzulia.irawati@yahoo.com
}

\begin{abstract}
Abstrak
Demam Berdarah Dengue (DBD) masih merupakan masalah kesehatan masyarakat terpenting di Indonesia. Penyakit ini disebabkan oleh virus dengue, yang disebarkan melalui gigitan nyamuk Aedes aegypti sebagai vektor utama. Penyakit ini menyebar bersamaan dengan peningkatan mobilitas penduduk, kepadatan penduduk dan transportasi. Penyelidikan telah dilakukan dalam rangka memperoleh jawaban tentang kepadatan vektor DBD di Perumnas Siteba menggunakan metode penelitian Survey Deskriptif (Cross Sectional). Dalam hal ini, 100 buah rumah digunakan sebagai sampel sedangkan teknik pengambilan sample adalah Multi Stage Random Sampling. Hasil yang didapatkan 33\% rumah dan $20.7 \%$ kontainer positif mengandung larva aedes dan $100 \%$ berupa Aedes aegypti. Kesimpulan dari penelitian ini adalah kepadatan vektor DBD di Perumnas Siteba Padang cukup tinggi dengan ratio 3: 1, dengan vektornya Aesdes aegypti. Hal ini dapat dilihat dari salah satu rumah yang positif larva Aesdes aegypti.
\end{abstract}

Kata lunci : Aedes aegypti, Dengue Haemorrhagic fever (DHF)

\begin{abstract}
Dengue Hemorrhagic fever (DHF) is still an critical community health problem in Indonesia. This disease is caused by Dengue Virus, which is spread through Aedes aegypti's bite as the main vector. This disease spread together along with the increasing of people's mobiliy, the population density and the transportation. The research has been done in order to get the description of the density Of DHF vector in Perumnas Siteba by using Descriptive Survey (Cross Sectional) research method. In this case, one hundred houses are used as the sample, while the technique of taking the sample is in Multistage Random Sampling. The result of above $33 \%$ house and $20.7 \%$ the containera, positively with Aedes larva and almost 100\% vector's species are Aedes aegypti. In this respect, it can be concluded that the density of DHF Vector in Perumnas Siteba Padang is ther high, in ratio 3:1. It can be seen from one of three houses are positive with Aedes aegypti larvae.
\end{abstract}

Key word: Aedes aegypti, Dengue Haemorrhagic fever (DHF) 


\section{Pendahuluan}

Penyakit Demam Berdarah Dengue (DBD) masih merupakan masalah kesehatan masyarakat di Indonesia. Meskipun upaya penanggulangan yang dilakukan telah berhasil menurunkan angka kematian dari $41 \%$ pada tahun 1968 menjadi 2,5\% pada tahun 1996, namun kecenderungan peningkatan insiden dan penyebarluasan penyakit ini belum berhasil dikendalikan. $^{(1,3,7,8)}$

Pada awalnya penyakit DBD hanya ditemukan di daerah perkotaan yang padat penduduknya, tetapi sekarang sudah meluas sampai ke daerah sub-urban dan pedesaan. Karena virus penyebab dan vektor penularnya tersebar luas di seluruh pelosok tanah air (kecuali daerah ketinggian lebih dari pada $1000 \mathrm{~m}$ diatas permukaan laut) sepanjang tahun dengan kepadatan populasi akan meningkat pada musim hujan. Meningkatnya mobilitas penduduk dan arus transportasi merupakan hal yang memegang peranan dalam penyebaran DBD..$^{(1,4,5,11,14)}$

Penyakit DBD disebabkan oleh virus dengue yang disebarkan melalui gigitan nyamuk Aedes aegypti sebagai vektor utamanya, yang mempunyai tempat istirahat dan aktifitas di dalam rumah (in door), disamping Aedes albopictus sebagai vektor potensial dengan tempat istirahat di luar rumah (out door). Secara sengaja atau tidak, tempat perindukan nyamuk ini telah dibuat oleh manusia sendiri berupa tempayan, bak mandi, drum, genangan air yang tidak berhubungan langsung dengan tanah seperti ban bekas, kaleng bekas yang berisi air hujan, tempat minum burung, vas bunga dan aki bekas. ${ }^{(2,6,9,11)}$

Dari berbagai tempat perindukan ini, bak mandi merupakan tempat penampungan air (TPA) yang paling banyak mengandung larva karena volumenya lebih besar dibanding tempat yang lain. ${ }^{(4,9-13)}$

Kota Padang dengan jumlah penduduk pada tahun 2007 sebanyak 710.511 jiwa merupakan daerah dengan angka kesakitan DBD tertinggi dibanding daerah lainnya di Sumatera Barat. Menurut data dari Kanwil Depkes Sumatera Barat tahun 2006 dilaporkan sebanyak 103 Orang penderita DBD, sedangkan tahun 2007 menjadi 107 orang. Sementara angka kematian penderita DBD di Padang masih tinggi yaitu $4,8 \%$ pada tahun 2006 dan 5,9 pada tahun 2007. Pada tahun 2008 ini sampai bulan Oktober dilaporkan kasus penderita DBD sebanyak 202 orang dengan 15 orang meninggal dunia.

Kelurahan Surau Gadang termasuk salah satu kelurahan endemis DBD di Kota Padang, yang berada di dalam wilayah kerja Puskesmas Nanggalo. Di kelurahan ini terdapat beberapa kawasan perumahan, salah satunya adalah Perumnas Siteba. Di perumnas ini setiap tahunnya pernah dilaporkan adanya kasus DBD. Pada tahun 2008 ini dilaporkan sebanyak 14 orang penderita DBD, satu diantaranya meninggal dunia.

Mengingat sampai sekarang belum ditemukan obat atau vaksin yang dapat membunuh virus Dengue, maka penanggulangannya berupa perwatan penderita secara intensif dan tidak kalah pentingnya adalah pemberantasan terhadap vektor DBD berupa pemberantasan sarang nyamuk (PSN) dan tempat perindukan larva untuk memutuskan rantai kehidupan nyamuk. Agar lebih efektifnya kegiatan tersebut, khususnya di daerah Perumnas Siteba maka perlu diketahui bagaimana kepadatan vektor di daerah ini, spesies vektornya serta tempat perindukan yang disenangi oleh vektor. 


\section{BAHAN DAN CARA KERJA}

Penelitian ini dilaksanakan pada tahun 2008 dan mengambil lokasi di Perumnas Siteba Kelurahan Surau Gadang Kecamatan Nanggalo Kota Padang. Penelitian ini dilakukan dengan jenis Survei Deskriptif (Cross Sectional). Populasi pada penelitian ini adalah seluruh rumah yang ada di Perumnas Siteba. Sampel diambil sebanyak 100 rumah secara Multistage Random Sampling. Data vektor DBD di peroleh dengan cara survei larva di berbagai tempat perindukan dengan, etode single larva method. Identifikasi larva dilakukan di Laboratorium Parasitologi Fakultas Kedokteran Universitas Andalas Padang.

\section{HASIL DAN DISKUSI}

Dari hasil penelitian didapatkan data dalam Tabel 1. Kepadatan vektor DBD di perumnas Siteba pada tahun 2008, pada Tabel 1 menunjukkan $\mathrm{HI}=$ $33 \%, \mathrm{CI}=20,7 \%$ dan $\mathrm{BI}=35 \%$.

Hasil yang diperoleh tidak jauh berbeda dari penelitian yang dilakukan oleh Depkes (2006-2007) di beberapa kota di Indonesia termasuk Padang. House Index $(\mathrm{HI})=35 \%$ berarti diantara 3 rumah positif. ABJ (angka bebas jentik) nyamuk di daerah endemi 2006 adalah 77,50\%, dibandingkan dengan hasil penelitian ini ternyata angka-angka yang didapatkan cukup tinggi. Kondisi ini disebabkan kurang- nya partisipasi masyarakat dalam rangka pemberantasan sarang nyamuk. Vektor DBD di Perumnas Siteba Padang lebih menyukai tempat perindukan di dalam rumah dibandingkan di luar rumah. Ini terlihat dari angka wadah (Container Index) di dalam rumah lebih tinggi dibandingkan di luar rumh. CI di dalam rumah $18,34 \%$, sedangkan CI di luar rumah hanya $2,37 \%$. Hal ini terjadi akibat banyaknya wadah-wadah yang bertebaran di dalam rumah sehingga memberikan kemungkinan bagi nyamuk untuk meletakkan telur-telurnya.

Pada Tabel 3 terlihat : Tempat perindukan vektor DBD di Perumnas Siteba Padang terbanyak ditemukan pada bak mandi yang terbuat dari semen. Dengan CI $=11,24 \%$, menyusul kemudian bak mandi yang terbuat dari porselen dengan $\mathrm{CI}=7,1 \%$. Sementara pada kolam, sumur dan pot bunga tidak ditemukan adanya larva dengan CI masing-masing 0\%. Hasil yang diperoleh hampir sama dengan hasil yang didapatkan oleh Sungkar pada tahun 2005.

Hampir 100\% vektor DBD di Perumnas Siteba yang ditemukan pada survei bulan Nopember 2009 adalah jenis Aedes aegypti. Pada Tabel 4 juga terlihat bahwa Aedes aegypti lebih menyukai tempat perindukan di dalam rumah $(88,6 \%)$ dibandingkan di luar rumah $(11,4 \%)$.

Tabel 1 : Distribusi kepadatan vektor DBD di Perumnas Siteba Padang pada Survei tahun 2008

\begin{tabular}{|c|c|c|c|c|c|c|}
\hline \multicolumn{2}{|c|}{ Jumlah Rumah } & \multirow[b]{2}{*}{ HI (\%) } & \multicolumn{2}{|c|}{ Jumlah Kontainer } & \multirow[b]{2}{*}{ CI $(\%)$} & \multirow[b]{2}{*}{ BI $(\%)$} \\
\hline $\begin{array}{c}\text { Yang } \\
\text { diperiksa }\end{array}$ & (+) larva & & $\begin{array}{c}\text { Yang } \\
\text { diperiksa }\end{array}$ & (+) larva & & \\
\hline 100 & 33 & 33 & 169 & 35 & 20,71 & 35 \\
\hline
\end{tabular}


Keterangan :

$\mathrm{HI}=$ House Index $=\frac{\text { JumlahrumahyangpositiflarvaAedes }}{\text { Jumlahrumahyangriperiksa }} \times 100 \%$

$\mathrm{CI}=$ Container Index $=\frac{\text { JumlahwadahyangpositiflarvaAedes }}{\text { Jumlahwadahyangdiperiksa }} \times 100 \%$

$\mathrm{BI}=$ Breteau Index $=$ Jumlah Wadah yang Positif dengan Larva Aedes dalam 100 rumah yang diperiksa.

Tabel 2: Distribusi Container Index (CI) berdasarkan letak container di luar/dalam rumah

\begin{tabular}{|c|c|c|c|}
\hline \multirow{2}{*}{ Container } & \multicolumn{2}{|c|}{ Jumlah Container } & \multirow{2}{*}{ CI $(\%)$} \\
\hline & Yang diperiksa & (+) larva & \\
\hline Di luar ruma & 43 & 4 & 2,37 \\
\hline Di dalam rumah & 126 & 31 & 18,34 \\
\hline
\end{tabular}

Keterangan : $\mathrm{CI}=$ Container Index $\mathrm{X}^{2}=4,89$

$$
\mathrm{df}=1(\mathrm{P}<0,05)
$$

Tabel 3. Distribusi Tempat Perindukan Vektor DBD di Perumnas Siteba Padang pada Survei tahun 2008

\begin{tabular}{|c|c|c|c|}
\hline \multirow[t]{2}{*}{ Jenis Container } & \multicolumn{2}{|c|}{ Jumlah Container } & \multirow[t]{2}{*}{ CI (\%) } \\
\hline & $\begin{array}{l}\text { Yang } \\
\text { diperiksa }\end{array}$ & $\begin{array}{l}(+) \\
\text { larva }\end{array}$ & \\
\hline $\begin{array}{l}\text { a. Bak mandi yang terbuat dari } \\
\text { porselen }\end{array}$ & 59 & 12 & 7,10 \\
\hline b. Bak mandi yang terbuat dari semen & 41 & 19 & 11,24 \\
\hline c. Ban bekas & 2 & 2 & 1,18 \\
\hline d. Drum bekas & 1 & 1 & 0,59 \\
\hline e. Tempat minum burung & 14 & 1 & 0,59 \\
\hline f. Kolam & 13 & 0 & 0 \\
\hline g. Sumur & 18 & 0 & 0 \\
\hline h. Aquarium & 4 & 0 & 0 \\
\hline i. Ember penampung air minum & 16 & 0 & 0 \\
\hline j. Pot bunga & 1 & 0 & 0 \\
\hline \multicolumn{4}{|c|}{$\begin{array}{l}\text { Keterangan : } C I=\text { Container Index, } X^{2}=7,63 \\
d f=1(P<0,05) \\
\text { Tabel 4. Jenis vektor DBD pada survei tahun } 2008 \text { di Perumnas Siteba Padang } \\
\text { berdasarkan tempat perindukan }\end{array}$} \\
\hline \multirow{2}{*}{ Letak Container } & \multicolumn{3}{|c|}{ Jenis larva } \\
\hline & $\%$ & Ae. albopictus & $\%$ \\
\hline Di luar rumah & 11,40 & 0 & 0 \\
\hline Di dalam rumah & 88,60 & 0 & 0 \\
\hline Jumlah & 100 & 0 & 0 \\
\hline
\end{tabular}




\section{KESIMPULAN}

Setelah dilakukan survei jentik di Perumnas Siteba Padang pada tahun 2008 diperoleh hasil yang dapat disimpulkan sebagai berikut :

1. Kepadatan vektor DBD di Perumnas Siteba cukup tinggi, dengan ratio satu diantara 3 rumah positif dengan jenitik nyamuk Aedes.

2. Jenis vektor DBD yag ditemukan adaLah Ae. aegypti.

3. Ae. aegypti lebih menyukai tempat perindukan di dalam rumah dari pada di luar rumah.

4. Tempat perindukan yang paling disenangi adalah bak mandi.

5. Bak mandi dari semen lebih disenangi daripada bak mandi dari porselen.

\section{KEPUSTAKAAN}

1. Achmad H. Pergerakan Peran serta Masyarakat dalam Pemberantasan Sarang yamuk DBD. Ditjen PPM \& PLP, Depkes RI, Jakarta , 1997.

2. Agoes, R., Oehadian,H, dan Natadisastra,D. 1997.

Bungarampai Entomolgi Medik. FKUP: Penerbit Bagian Parasitologi.

3. Agoes,R. 2002. Scabies: The Concept of Prevention and Community Treatment in Indonesia. Proceeding: First Interrnational Scientific Meeting on Immuno and Tropical Dermatology. Denpasar, Indonesia.

4. Anonymous.

Direktorat Jenderal Pemberantasan Penyakit Menular dan Penyehatan Lingkungan Pemukiman. Depkes RI, 2006.
5. Bahr M. and Bell D.R. 1991. Manson's Tropical Diseases, $9^{\text {th }}$ Edition. London: Bailiere Tindal.

6. Furman, DP and Catts,Ep. 1986. Manual of medical Entomology. London : Cambridge University Press.

7. Jayaram Paniker, CK. 1997. Textbook of Medical Prasitology, $4^{\text {th }}$ Ed. New Delhi : Jaypee Brothers Med. Publishers (P). Ltd.

8. Mohr, C.van der meer. 1958. Parasit-parasit Hewani yang utama pada manusia. Bagian II: Arthropoda. Medan : Penerbit Fakultas Kedokteran Negeri Medan.

9. Ramdja M, C. Anwar, S. Waiman. 2000. Pengaruh frekuensi pemberian darah manusia terhadap kemampuan bertelur nyamuk demam berdarah Aedes aegypti. Majalah Kedokteran Sriwijaya, Vol.32, No.1. Jan. 2000

10. Sukana B. 1993. Pemberantasan Vektor DBD di Indonesia. Media Litbangkes Vol. VII. No.1

11. Sumarno. 1983. Demam Berdarah dengue pada anak. UI Press, Jakarta

12. Suroso T. Kebijakan Nasional pada Demam Berdarah Dengue. Cermin Dunia Kedokteran, 1982; $81: 14-16$. 
13. Toma T, I. Miyagi. 1986. the mosquito fauna of the ryukyu archipelago identification keys, pupal description and notes on biology, medical importance and distribution. Mosquito systematic, Japan. Vol.18 (10).
14. Wulandari TK. 2001. Vektor demam berdarah dan penanggulangannya. Mutiara Medika, Vol.1. No.1; 27-30. 